\title{
Control of the Ratio of Inducer to Cell Concentration to Enhance the Phytase Production in Recombinant Pichiapastoris
}

\author{
Housheng Hong ${ }^{1, *}$, Zhaosheng $\mathrm{Min}^{2}$, Huiming Guo ${ }^{2}$ \\ ${ }^{1}$ College of Biotechnology and Pharmaceutical Engineering, Nanjing Tech University, Nanjing, China \\ ${ }^{2}$ College of Sciences, Nanjing Tech University, Nanjing, China \\ *Corresponding author: hhs@njtech.edu.cn
}

Received November 12, 2014; Revised November 18, 2014; Accepted November 21, 2014

\begin{abstract}
Phytase production by Pichiapastoris was used as a case to study the mechanism and strategy for optimization of heterologous protein production. It was found that the ratio of inducer-methanol to cell concentration had a significant influence on phytase production. In this case, we found that the optimum initial cell concentration and methanol concentration were $85 \mathrm{~g} / \mathrm{L}$ and $10 \mathrm{~g} / \mathrm{L}$, respectively. During induction period, an easy-to-control methanol feeding method was proposed according to the optimal ratio of methanol to cell concentration at a range of $0.063-0.132 \mathrm{~g} / \mathrm{g}$, and phytase activity and productivity reached $53984 \mathrm{U} / \mathrm{mL}$ and $529.25 \mathrm{U} /(\mathrm{mL} \cdot \mathrm{h})$, respectively. The method for optimization of phytase production through controlling the optimal ratio maybe provide an alternative idea to enhance other heterologous protein production with $P$. pastoris.
\end{abstract}

Keywords: Pichiapastoris, feeding strategy, methanol concentration, cell concentration, heterologous proteins

Cite This Article: Housheng Hong, Zhaosheng Min, and Huiming Guo, "Control of the Ratio of Inducer to Cell Concentration to Enhance the Phytase Production in Recombinant Pichiapastoris." Journal of Food and Nutrition Research, vol. 2, no. 12 (2014): 980-984. doi: 10.12691/jfnr-2-12-19.

\section{Introduction}

In biological system, hydrolysis of phytic acid (the principle storage form of phosphorus in legumes, cereals, oil seeds and nuts) to myo-inositol and inorganic phosphate is an important reaction for energy metabolism, metabolic regulation and signal transduction pathways [1]. The reaction was primarily catalyzed by phytase [2]. So far, phytase has been widely used in feed industry, and also applied to food and beverage industries and so on [3]. Along with the fast development of genetic engineering, genes encodingphytase have been cloned and expressed from many microorganisms' strains [4]. Due totheadvantages of producing large quantities of heterologous proteins and capability for large-scale production, $P$. pastoris is widely being used for research and production of variousforeign proteins $[5,6,7]$. Follow the manual instructions; two-step fermentation is the fundamental method to express heterologous protein in $P$. pastoris [8]. A cell high-density growth with glycerin or glucose as carbon source is just the first stage, and the second is generally called induction phase, in which methanol is added for biosynthesis of the recombinant protein under the control of a tightly regulated alcohol oxidase (AOX1) promoter. When the carbon source is switched from glucose to methanol, the response of recombinant cultures to induction of heterologous proteins involves significant changes in cellular physiology, growth rate and metabolism $[9,10,11,12]$.
It has been proved that cell concentration at the beginning of the second phase plays a significant role in recombinant protein production in many literatures $[13,14]$. Moreover different glucose feeding strategies have also been explored at the first phase of high-density cultivation. Thus,in order to reach high productivity of heterologous proteins, the cell concentration must be further increased [13,15,16,17]. For methanol induction phase, it has been one of the hottest topics in biochemical engineering to explore the method for methanol feeding so as to realize the high-efficient expression of heterologous protein in $P$. pastoris $[16,18,19,20]$. However, though various bioprocess strategies possibly related to metabolism have been studied for the methanol feeding, based on kinetics parameters such as oxygen consumption and methanol consumption, low expression efficiency of target protein shouldoccur, because $P$. pastoris cells compete to each other for methanolwhich is the only carbon source for cell growth and protein expression. Therefore, it is conceivable that methanol would be primarily used for heterologous protein expression not for cell growth under the non-limited methanol concentration, if cell concentration at the beginning of methanol induction phase reached very high levels [21,22]. Meanwhile, whatever the cell concentration is, the methanol concentration could be adjusted timely to ensure that the recombinant protein could be effectively induced, if the methanol was added through the ratio of methanol to cell concentration.

In this study, with the purpose of further increasing phytase production by $P$. pastoris, the impact of the initial 
cell concentration and the ratio of methanol to cell concentration during the methanol induction phase were carefully investigated. Our results showed that adopt the methanol feeding method based upon the optimal ratio of methanol to cell concentration could be usefully expressed phytase. Furthermore, we hold that the strategy maybe applied to other heterologous protein fermentation processes.

\section{Materials and Methods}

\subsection{Strain}

P. pastoris H311 (Mut ${ }^{+}$) used in this study was developed and provided by the YunnanNormalUniversity research group.

\subsection{Media}

YPD medium, containing yeast extract $10 \mathrm{~g} / \mathrm{L}$, peptone $20 \mathrm{~g} / \mathrm{Land}$ glucose $20 \mathrm{~g} / \mathrm{L}$, was used for seed culture. The basal salts medium for fermentation contained $(\mathrm{g} / \mathrm{L})$ : glucose 50, $\mathrm{KH}_{2} \mathrm{PO}_{4} 40, \mathrm{MgSO}_{4} \cdot 7 \mathrm{H}_{2} \mathrm{O}$ 14.9, $\mathrm{CaSO}_{4}$ $2 \mathrm{H}_{2} \mathrm{O}$ 0.39, $\left(\mathrm{NH}_{4}\right)_{2} \cdot \mathrm{SO}_{4} 30$ and $4.3 \mathrm{~mL} / \mathrm{L}$ of PTM1 trace metal solution. PTM1 solution contained (g/L): $\mathrm{CuSO}_{4} \cdot 5 \mathrm{H}_{2} \mathrm{O}$ 6, KI 0.09, $\mathrm{MnSO}_{4} \cdot \mathrm{H}_{2} \mathrm{O} \quad 3, \mathrm{H}_{3} \mathrm{BO}_{3}$ 0.02, $\mathrm{MoNa}_{2} \mathrm{O} 4 \cdot 2 \mathrm{H}_{2} \mathrm{O} \quad 0.2, \mathrm{CoCl}_{2}$ 0.5, $\mathrm{ZnCl}_{2} 20, \mathrm{FeSO}_{4} \cdot 7 \mathrm{H}_{2} \mathrm{O}$ 65 , biotin 0.2 and $\mathrm{H}_{2} \mathrm{SO}_{4} 5.0 \mathrm{~mL} / \mathrm{L}$. The feeding medium used in glucose fed-batch cultivation contained $50 \%(\mathrm{w} / \mathrm{v})$ glucose supplemented with $12 \mathrm{~mL} / \mathrm{L}$ PTM1 solution. The feeding medium used in methanol fed-batch phase was the pure methanol with $12 \mathrm{~mL} / \mathrm{L}$ PTM1 solution.

\subsection{Fermentation Conditions}

The seed culture was prepared from a $600 \mu \mathrm{L}$ frozen cell stock vial and cultured for $24 \mathrm{~h}$ in $50 \mathrm{~mL}$ YPD medium in a $500-\mathrm{mL}$ shake flask at $30^{\circ} \mathrm{C}$ and $220 \mathrm{r} / \mathrm{min}$. $10 \%(\mathrm{v} / \mathrm{v})$ of inoculum was inoculated into the basal salts medium in a 5-L fermentor(Nanjing Highke Bioengineering Equipment Co., ltd. China) with 2 L basal salts medium. The $\mathrm{pH}$ of the medium was adjusted and controlled at 5.0 with the addition of $25 \%$ ammonium hydroxide and $30 \%$ phosphoric acid. The temperature was controlled at $30^{\circ} \mathrm{C}$, and dissolved oxygen (DO) level was maintained over $20 \%$ of air saturation by a cascaded control of agitation rate from $500 \mathrm{r} / \mathrm{min}$ to $1000 \mathrm{r} / \mathrm{min}$ and aeration rate from $3.5 \mathrm{~L} / \mathrm{min}$ to $6 \mathrm{~L} / \mathrm{min}$. When glucose was exhausted, indicated by a rapid increase of DO, fed-batch was started by feeding $50 \%(\mathrm{w} / \mathrm{v})$ glucose plus $12 \mathrm{~mL} / \mathrm{L}$ PTM1. Before starting methanol induction phase, the glucose feeding was stopped for $4 \mathrm{~h}$ to avoid repression of AOX promoter. When dissolved oxygen level rose up to $80 \%$, the induction culture was initiated by feeding methanol plus $12 \mathrm{~mL} / \mathrm{L}$ PTM1. The glucose fed-batch culture and induction culture were performed in different strategies as follows.

\subsubsection{Different Cell Concentration at the Beginning of Induction}

The study used regular feeding scheme. The glucose fed-batch mode was started by adding a 50\% glucose solution at a constant flow rate of $25 \mathrm{~mL} / \mathrm{h}$ till cell concentration reached $45 \mathrm{~g} / \mathrm{L}, 65 \mathrm{~g} / \mathrm{L}$ and $85 \mathrm{~g} / \mathrm{L}$, respectively. During the post-induction phase, the methanol feeding rate was at $5 \mathrm{~mL} / \mathrm{h}$, and was adjust offline by gas chromatography every hour to maintain the residual methanol concentration at $5 \mathrm{~g} / \mathrm{L}$.

\subsubsection{Methanol Feeding Scheme to Enhance Heterologous Phytase Production}

With the purpose tomaintain the ratio of methanol to cell concentration during induction phase, methanol fedbatch cultivation was started as follows: (1) gradually increase the feeding rate of methanol from $5 \mathrm{~mL} / \mathrm{h}$ to 12 $\mathrm{mL} / \mathrm{h}$ in induction prophase $(0-10 \mathrm{~h})$, (2)adjust the methanol feeding rate to $15 \mathrm{~mL} / \mathrm{h}$ to maintain the methanol concentration at $13 \mathrm{~g} / \mathrm{L}$ in induction mid-phase (10-96 h), and (3) decrease the feeding rate of methanol to $5 \mathrm{~mL} / \mathrm{h}$ upon the increase of DO in later stage (after $96 \mathrm{~h}$ ).

\subsection{Cell Concentration Determination}

Cell concentration was measured using a spectrophotometer (Biospe-1601; Shimadzu Co., Kyoto, Japan) at $600 \mathrm{~nm}$ after an appropriate dilution. The optical density (OD600) value was converted to dry cell weight (DCW) according to a predetermined calibration line [OD600: DCW $(\mathrm{g} / \mathrm{L})=$ 1: 0.19$]$. $10 \mathrm{~mL}$ sample was collected and centrifuged at $10,000 \times \mathrm{g}$ for $10 \mathrm{~min}$, and the supernatant was frozen for determination.

\subsection{Phytase Activity Assay}

One unit of phytase activity (U) was defined as the amount of enzyme that catalyzes the release of $1.0 \mu \mathrm{mol}$ of inorganic phosphate per minute from $5.0 \mathrm{mM}$ sodium phytase in $\mathrm{pH} 5.5$ buffer at $37^{\circ} \mathrm{C}$. The fermentation broth samples were properly diluted by the acetate buffer $(0.25$ $\mathrm{M}, \mathrm{pH}$ 5.50) containing Triton X-100 and BSA, until the absorbance below could be linearly quantified by a UVvisible spectrophotometer (UVmini-1240, Shimadzu, Japan). Draw $0.2 \mathrm{~mL}$ of the diluted enzyme solution and $1.8 \mathrm{~mL}$ of the acetate buffer without Triton X-100 and BSA(0.25 M, pH 5.50) mixture, and were first pre-heated at $37^{\circ} \mathrm{C}$ for $5 \mathrm{~min}$, then $4.0 \mathrm{~mL}$ of substrate composed of $5.0 \mathrm{mM}$ sodium phytate (P8810, Sigma Co. Ltd., USA) was added. The mixture was reacted at $37^{\circ} \mathrm{C}$ for $30 \mathrm{~min}$ and the reaction was stopped by adding $4 \mathrm{~mL}$ freshly prepared color reagent (a concentration of $100 \mathrm{~g} / \mathrm{L}$ of ammonium molybdate solution, $2.35 \mathrm{~g} / \mathrm{L}$ solution of ammonium metavanadate and nitric acid solution(65\%) are mixed in the ratio of $1: 1: 2$ ) and cooled to room temperature (the color reagent was first added and the substrate solution was added at last in the blank group), then the solution was measured spectrophotometrically at $415 \mathrm{~nm}$. The standard curve was determined by adding color reagent to the different concentration of potassium phosphate monobasic solution at $37^{\circ} \mathrm{C}$ for $30 \mathrm{~min}$, followed by addition of substrate solution with the same procedure as mentioned above. Finally, according to the standard curve to calculate the linear regression equation of the amount of inorganic phosphorus, and then calculate the activity.

\subsection{Methanol Concentrations}

The residual methanol concentration was determined by gas chromatography (GC) with a flame-ionized detector 
(Shimadzu GC2010). A glass column (30 m×0.32 mm $0.50 \mu \mathrm{m})$ packed with PEG-20M was used. Injection, detector, and column temperature were $200^{\circ} \mathrm{C}, 220^{\circ} \mathrm{C}$, and $170^{\circ} \mathrm{C}$, respectively. The gas flow rate of nitrogen, hydrogen, and air were $40 \mathrm{~mL} / \mathrm{min}, 40 \mathrm{~mL} / \mathrm{min}$, and 450 $\mathrm{mL} / \mathrm{min}$, respectively. The chromatographic quantitative analysis was performed by internal standard method.

\section{Results and Discussion}

\subsection{Effects of Initial Cell Concentration in the Beginning of Induction Phase on Phytase Expression}

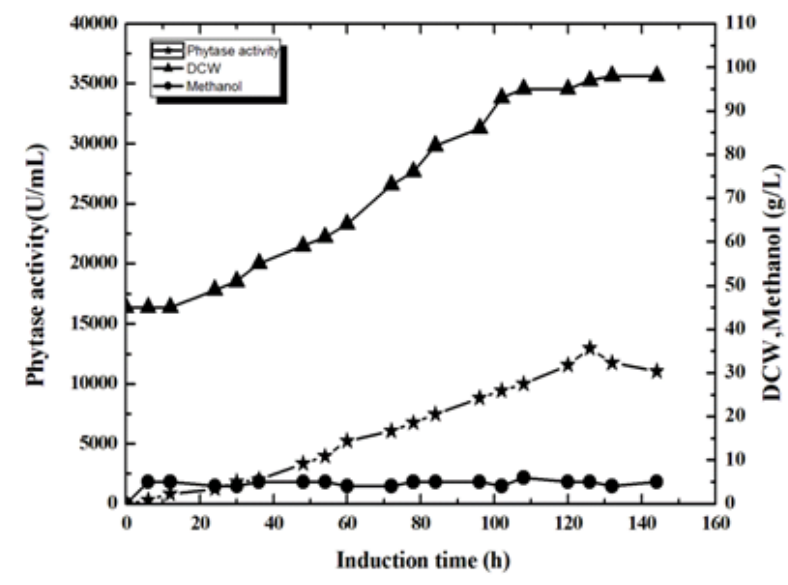

Fig.1-1
Figure 1 showed that cell concentration increased quickly and the phytase production raised continuously with initial cell concentration at $45 \mathrm{~g} / \mathrm{L}$ by the regular methanol feeding strategy, and both reached their maximum values at $12965 \mathrm{U} / \mathrm{mL}$ and $98.5 \mathrm{~g} / \mathrm{L}$, respectively (Figure 1-1). It was observed that cell slow growth till the end of cultivation, which was potentially due to the limited space when cell concentration reached $85 \mathrm{~g} / \mathrm{L}$. On the other side, phytase production was $120.9 \%$ and $28.2 \%$ higher than those when the initial cell concentrations were at $45 \mathrm{~g} / \mathrm{L}$ and $65 \mathrm{~g} / \mathrm{L}$, respectively (Figure 1-3). Table 1 presents that the related fermentation process parameters of different initial cell concentrations at the beginning of induction phase.

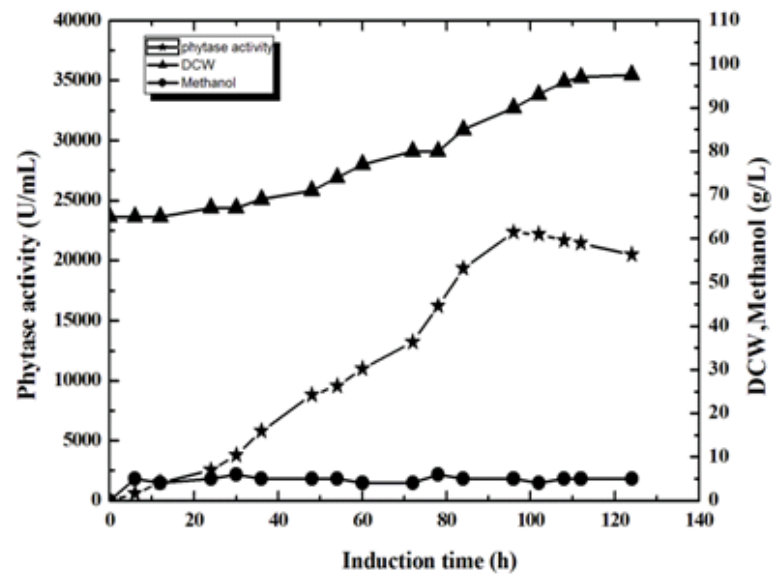

Fig.1-2

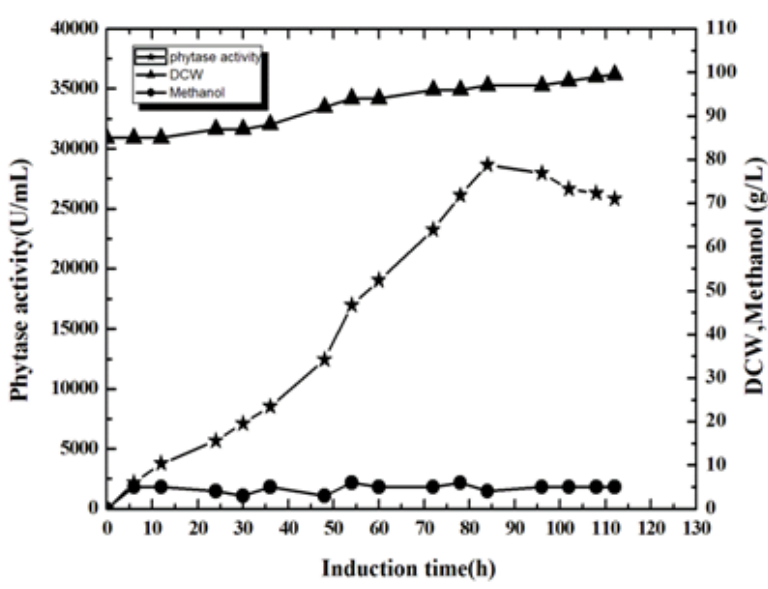

Fig. 1-3

Figure 1. Time courses of the cell concentration, phytase production and methanolconcentrations at different initial cellconcentrations controlled to 45g/L (Figure 1-1), 65 g/L(Figure 1-2) and 85 g/L (Figure 1-3) at the beginning of induction phase

Table 1. Comparison of fermentation process parameters for phytase production underdifferent modes of induction

\begin{tabular}{|c|c|c|c|c|c|}
\hline \multirow{2}{*}{ Fermentation process parameters } & \multicolumn{5}{|c|}{ Mode of cultivation } \\
\hline & I & II & III & IV & $\mathrm{V}$ \\
\hline Initial cell concentration (g/L) & 45 & 65 & 85 & 85 & 85 \\
\hline Average methanol concentration (g/L) & 5.0 & 5.0 & 5.0 & 10.0 & 15.0 \\
\hline Ratio of methanol to initial cell concentration (g/g) & 0.111 & 0.077 & 0.059 & 0.118 & 0.176 \\
\hline Maximum cell concentration (g/L) & 98.5 & 97.6 & 99.5 & 100.3 & 101 \\
\hline Maximum phytase $(\mathrm{U} / \mathrm{mL})$ & 12965 & 22335 & 28643 & 40582 & 18235 \\
\hline Total consumed methanol (g/L) & 230 & 240 & 223 & 234 & 276 \\
\hline Average specific phytase production rate (U/g/h) & 113 & 217 & 287 & 419 & 173 \\
\hline Yield of DCW on methanol (g/g) & 0.261 & 0.132 & 0.003 & 0.002 & 0.004 \\
\hline Yield of phytase on methanol (U/g) & 55 & 93 & 139 & 194 & 69 \\
\hline Phytase productivity (U/mL/h) & 102.9 & 102.9 & 341 & 398 & 190 \\
\hline
\end{tabular}


Due to there is almost no difference between three experiments in DO concentration, we assumed that the initial concentration was probably the prime reason that resulted in such an obvious difference of phytase production. With lower initial cell concentration, a higher percentage of assimilation of methanol into biomass while methanol oxidized to obtain the required energy for phytase production was reduced, in theory, make it possible. As demonstrated in Table 1, the yield of DCW on methanol with cell concentration at $45 \mathrm{~g} / \mathrm{L}$ was higher than that at cell concentration of $85 \mathrm{~g} / \mathrm{L}$, but the yield of phytase on methanol was much lower than that at cell concentration of $85 \mathrm{~g} / \mathrm{L}$. In addition, if the initial cells reached high level, they would contain high intracellular concentration of ribosome, which could contribute to synthesize a lot of key enzymes and recombinant foreign protein for the subsequent methanol metabolism when the carbon source was switched from glucose to methanol $[22,23]$.

\subsection{Effects of Methanol Concentration during Induction Phase on Phytase Production}

Phytase biosynthesis is controlled by the same promoter responsible for the synthesis of the methanol oxidase,thus methanol concentration was a key factor to be optimized. In our research, different concentrations of methanol for phytase expression were investigated via maintaining the initial cell concentration at $85 \mathrm{~g} / \mathrm{L}$ during induction phase. Table 1 presents the comparison of related fermentation process parameters at different methanol concentrations. In this study, we found that the $P$. pastoris strain had the ability to tolerant to high concentration of methanol. Moreover, it worked massive effectively under the nonrestricted methanol concentration. As illustrated in Figure 2, at the methanol concentration of $10 \mathrm{~g} / \mathrm{L}$, the phytase production was enhanced to $11944 \mathrm{U} / \mathrm{mL}$, which was $41.7 \%$ higher than that of methanol concentration at $5 \mathrm{~g} / \mathrm{L}$. When methanol concentration was controlled too high (15 $\mathrm{g} / \mathrm{L}$ ), phytase production was inhibited and the yield decreased. It was possibly due to the metabolic stress when the cell machinery was overburdened in high methanol concentration, which may give rise to physiological changes that negatively affected process performance $[24,25,26]$.

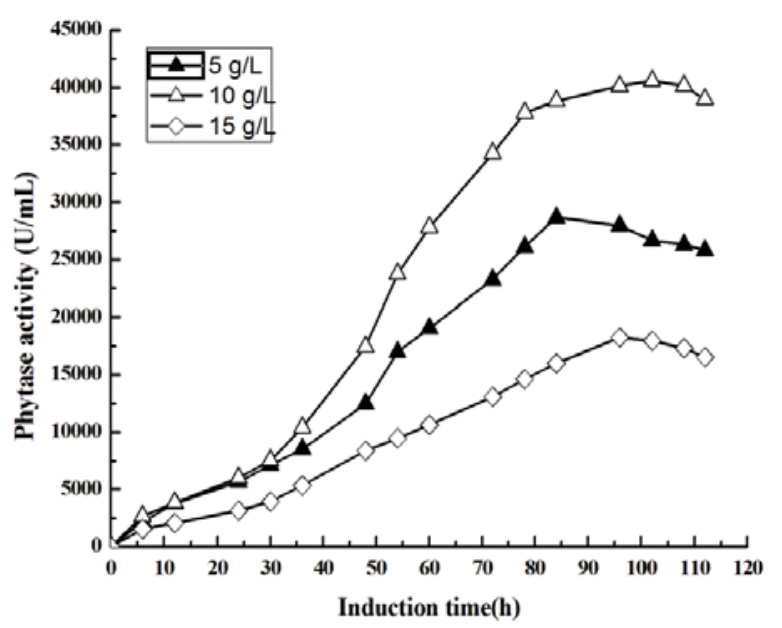

Figure 2. Time courses of phytase productionat differentmethanol concentrations in the induction phase. The methanol concentrationwas controlled at $5 \mathrm{~g} / \mathrm{L}, 10 \mathrm{~g} / \mathrm{Land} 15 \mathrm{~g} / \mathrm{L}$

\subsection{Effects of the Ratio of Methanol to Cell Concentration on Phytase Production}

A further study was implemented to research the impact of the ratio of methanol to cell concentration on phytase production when the initial cell concentration reached 85 $\mathrm{g} / \mathrm{L}$ at the beginning of induction phase. As shown in Figure 3, phytase production increased with the increment of the ratio from $0.063 \mathrm{~g} / \mathrm{g}$ to $0.173 \mathrm{~g} / \mathrm{g}$ and declined at a higher ratio of $0.228 \mathrm{~g} / \mathrm{g}$. As far as we know, it was the first time suggested that the application of the ratio of methanol to cell concentration for controlling methanol feeding to produce phytase in $P$. pastoris. Due to which has one big advantage over conventional feeding scheme.Whatever the cell concentration is, the methanol concentration could be adjusted timely to ensure that the phytase could be effectively induced in the induction phase.

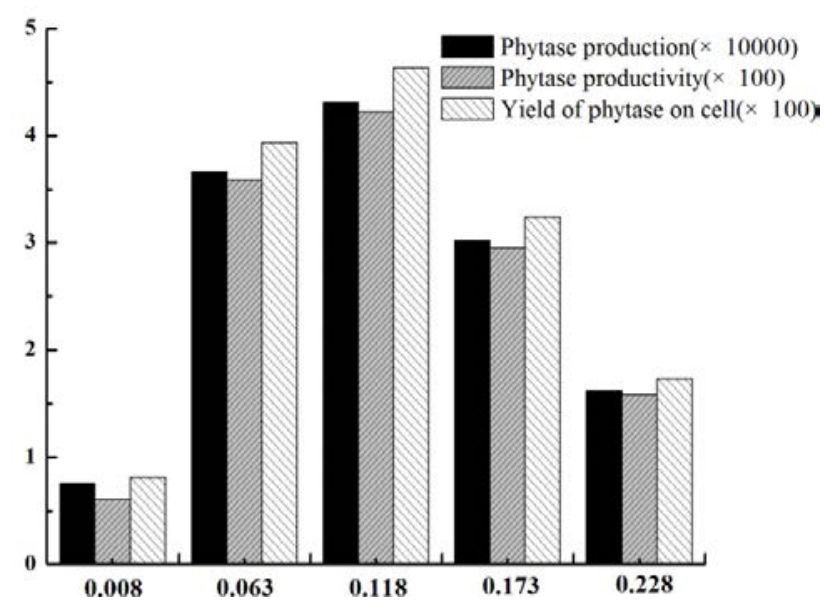

Figure 3. Effects of the ratio of methanol to cell concentration on phytase production $(\times 10000)$, phytase productivity $(\times 100)$ and yield of phytase on cell $(\times 100)$

\subsection{Enhancement of Phytase Production in Recombinant $P$. pastoris by Controlling the Ratio of Methanol to Cell Concentration}

For purpose of the high-efficient production of phytase, an optimization method was suggested to obtain the maximum phytase production. In the methanol induction phase, the methanol feeding strategy was adopted to keep the optimum ratio of methanol to cell concentration.

At the start of methanol induction phase, cells were in the transition stage from glucose to methanol metabolism and the specific methanol uptake rate increased gradually, the methanol feeding rate was increasingly fed step by step as described by $2.3[27,28,29]$. After the adaptation state, non-growth cells of $P$. pastoris maintained the specific methanol uptake rate constant with DO level at a range of $20-30 \%$. The feeding rate was maintained constant. Cellular metabolism ability start to decrease after $96 \mathrm{~h}$, which was reflected by the increase of DO concentration, and the specific methanol uptake rate also reduced. So, methanol feeding rate was decreased so as to reduce metabolic stress on $P$. pastoris cells. At last, results shows that by controlling the ratio between $0.063 \mathrm{~g} / \mathrm{g}$ and $0.132 \mathrm{~g} / \mathrm{g}$, phytase activity and productivity reached their maximal values of $53984 \mathrm{U} / \mathrm{mL}$ and $529.25 \mathrm{U} /(\mathrm{mL} \cdot \mathrm{h})$, respectively, which were 1.33-fold and 1.3-fold higher than those of the regular feeding scheme (Figure 4). 


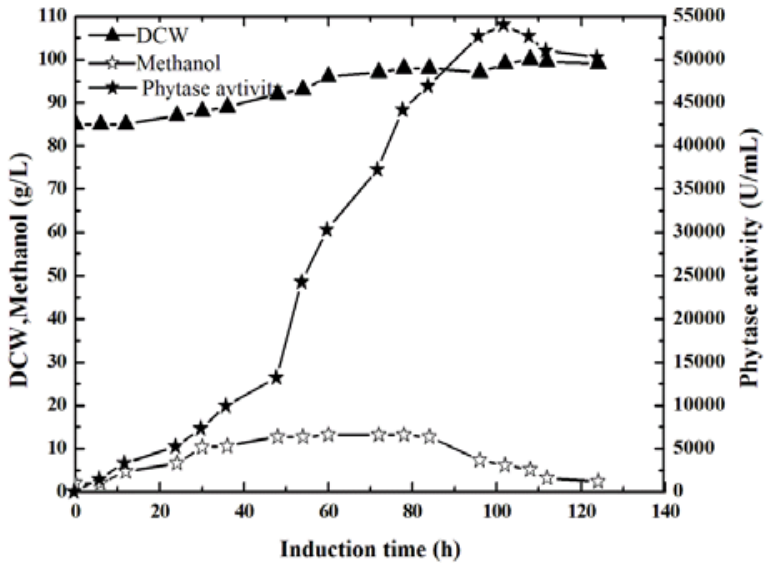

Figure 4. Effects of cell concentration, phytase production and methanolconcentration by controlling of the ratio of methanol to cell concentration

\section{Conclusions}

To our knowledge, it is the newly study the fed-batch application in phytase production from $P$. pastoris. It is no doubt that the results had presented that phytase production could be increased obviously with optimized production methods via controlling the ratio of methanol to cell concentration in the methanol fed-batch cultivations. High production of recombinant phytase may benefit to characterization of the molecules and their modes of action, and may broaden the application of phytase in industry. Meanwhile, it maybe provides an alternative strategy to enhance other heterologous protein production with $P$. pastoris.

\section{Acknowledgements}

This research was supported by the National High Technology Research and Development Program of China (863 Program) (No. 2012AA021201).

\section{References}

[1] Haefner S, Knietsch A, Scholten E, Braun J, Lohscheidt M, Zelder O: Biotechnological production and applications of phytases. Appl Microbiol Biot 2005, 68(5): 588-597.

[2] Lei XG, Porres JM: Phytase enzymology, applications, and biotechnology. Biotechnol Lett 2003, 25(21): 1787-1794.

[3] Kumar V, Sinha AK, Makkar HPS, Becker K: Dietary roles of phytate and phytase in human nutrition: A review. Food Chem 2010, 120(4): 945-959.

[4] Xiong AS, Yao QH, Peng RH, Han PL, Cheng ZM, Li Y: High level expression of a recombinant acid phytase gene in Pichia pastoris. J Appl Microbiol 2005, 98(2):418-428.

[5] Li P, Anumanthan A, Gao X, Ilangovan K, Suzara VV, Düzgüneș N, Renugopalakrishnan V: Expression of Recombinant Proteins in Pichia pastoris. Appl Biochem Biotech 2007, 142(2): 105-124.

[6] Romanos MA, Scorer CA, Clare JJ: Foreign gene expression in yeast: a review. Yeast 1992, 8(6): 423-488.

[7] Gellissen G: Heterologous protein production in methylotrophic yeasts. Appl Microbiol Biot 2000, 54(6): 741-750.

[8] Macauley-Patrick S, Fazenda ML, McNeil B, Harvey LM: Heterologous protein production using thePichia pastoris expression system. Yeast 2005, 22(4): 249-270.

[9] Cereghino J: Heterologous protein expression in the methylotrophic yeast Pichia pastoris. Fems Microbiol Rev 2000, 24(1):45-66.

[10] Khatri NK, Hoffmann F: Impact of methanol concentration on secreted protein production in oxygen-limited cultures of recombinantPichia pastoris. Biotechnol Bioeng 2006, 93(5):871879.
[11] Tang S, Boehme L, Lam H, Zhang Z: Pichia pastoris fermentation for phytase production using crude glycerol from biodiesel production as the sole carbon source. Biochem Eng J 2009, 43(2): 157-162.

[12] Doring F, Klapper M, Theis S, Daniel H: Use of the glyceraldehyde-3-phosphate dehydrogenase promoter for production of functional mammalian membrane transport proteins in the yeast Pichia pastoris. Biochem Biophys Res Commun 1998, 250(2): 531-535.

[13] Krause M, Ukkonen $K$, Haataja $T$, Ruottinen $M$, Glumoff $T$, Neubauer A, Neubauer P, Vasala A: A novel fed-batch based cultivation method provides high cell-density and improves yield of soluble recombinant proteins in shaken cultures. Microb Cell Fact 2010, 9: 11.

[14] Wei C, Zhou X, Zhang Y: Improving intracellular production of recombinant protein in Pichia pastoris using an optimized preinduction glycerol-feeding scheme. Appl Microbiol Biot 2008, 78(2): 257-264.

[15] Jahic M, Gustavsson M, Jansen A, Martinelle M, Enfors S: Analysis and control of proteolysis of a fusion protein in Pichia pastoris fed-batch processes. J Biotechnol 2003, 102(1): 45-53.

[16] Hellwig S, Emde F, Raven NP, Henke M, van Der Logt P, Fischer R: Analysis of single-chain antibody production in Pichia pastoris using on-line methanol control in fed-batch and mixed-feed fermentations. Biotechnol Bioeng 2001, 74(4): 344-352.

[17] Zheng J, Zhao W, Guo N, Lin F, Tian J, Wu L, Zhou H: Development of an industrial medium and a novel fed-batch strategy for high-level expression of recombinant $\beta$-mananase by Pichia pastoris. Bioresource Technol 2012, 118: 257-264.

[18] SCHENK J, MARISON I, VONSTOCKAR U: A simple method to monitor and control methanol feeding of Pichia pastoris fermentations using mid-IR spectroscopy. J Biotechnol 2007, 128(2): 344-353.

[19] Nakano A, Lee CY, Yoshida A, Matsumoto T, Shiomi N, Katoh S: Effects of methanol feeding methods on chimeric $\alpha$-amylase expression in continuous culture of Pichia pastoris. J Biosci Bioeng 2006, 101(3): 227-231.

[20] Qureshi MS, Zhang D, Du G, Chen J: Improved production of polygalacturonate lyase by combining a $\mathrm{pH}$ and online methanol control strategy in a two-stage induction phase with a shift in the transition phase. J Ind Microbiol Biot 2010, 37(4): 323-333.

[21] Celik E, Calık P, Oliver SG: Fed-batch methanol feeding strategy for recombinant protein production by. Yeast 2009, 26(9): 473-484

[22] Sreekrishna K, Brankamp RG, Kropp KE, Blankenship DT, Tsay JT, Smith PL, Wierschke JD, Subramaniam A, Birkenberger LA: Strategies for optimal synthesis and secretion of heterologous proteins in the methylotrophic yeast Pichia pastoris. Gene 1997, 190(1): 55-62.

[23] Jungo C, Rérat C, Marison IW, von Stockar U: Quantitative characterization of the regulation of the synthesis of alcohol oxidase and of the expression of recombinant avid in a Pichia pastoris Mut+ strain. Enzyme Microb Tech 2006, 39(4): 936-944.

[24] Minning S, Serrano A, Ferrer P, Sola C, Schmid RD, Valero F: Optimization of the high-level production of Rhizopus oryzae lipase in Pichia pastoris. J Biotechnol 2001, 86(1): 59-70.

[25] Sinclair G, Choy FY: Synonymous codon usage bias and the expression of human glucocerebrosidase in the methylotrophic yeast, Pichia pastoris. Protein Expr Purif 2002, 26(1):96-105.

[26] Plantz BA, Sinha J, Villarete L, Nickerson KW, Schlegel VL: Pichia pastoris fermentation optimization: energy state and testing a growth-associated model. Appl Microbiol Biot 2006, 72(2): 297305.

[27] Min C, Lee J, Chung K, Park H: Control of specific growth rate to enhance the production of a novel disintegrin, saxatilin, in recombinant Pichia pastoris. J Biosci Bioeng 2010, 110(3): 314319.

[28] Zhou X, Zhang Y: Decrease of proteolytic degradation of recombinant hirudin produced by Pichia pastoris by controlling the specific growth rate. Biotechnol Lett 2002, 24(17): 1449-1453.

[29] Ren H, Yuan J: Model-based specific growth rate control forPichia pastoris to improve recombinant protein production. Journal of Chemical Technology \& Biotechnology 2005, 80(11): 1268-1272.

[30] Charoenrat T, Ketudat-Cairns M, Stendahl-Andersen H, Jahic M, Enfors S: Oxygen-limited fed-batch process: an alternative control for Pichia pastoris recombinant protein processes. Bioproc Biosyst Eng 2005, 27(6): 399-406. 